\title{
A STUDY OF PROTEUS INFECTIONS IN A MALE UROLOGICAL WARD
}

\author{
BY \\ P. W. KIPPAX \\ From St. James's Hospital, Balham, London
}

(RECEIVED FOR PUBLICATION MAY 26, 1956)

During 1954 the high incidence of Proteus infections in a ward devoted to male urological surgery gave cause for concern. In an attempt to bring the infection under control a detailed study was made of the organisms concerned and the results were correlated with the characters of Proteus organisms isolated elsewhere in the hospital.

The work reported here is an account of some aspects of this study.

\section{Scheme of Study}

All samples of urine received from a 22-bed male urological ward, on which bacteriological examination was requested, were examined for Proteus. All swabs from post-operative wound infections in the same ward were similarly examined for Proteus. When the organism was isolated, precise definition of species and strain was attempted, and any possible source of a homologous strain was sought.

\section{Isolation of Organisms}

Specimens of urine were obtained by the "midstream" technique. When received in the laboratory they were centrifuged for five minutes at 2,000 r.p.m., and the deposits were plated on MacConkey's agar and on blood agar containing "dispersol" L.N. (Mackie and McCartney, 1948). Preliminary serial subcultures of known strains of Proteus had failed to show any change in the biochemical reactions of the organisms due to growth on "dispersol "-blood agar.

Cultures of organisms isolated were maintained during routine testing on nutrient agar slopes in bijou bottles, and a number of representative strains were preserved in glass ampoules by freeze drying.

\section{Definition and Identification of Strains}

Hauser in 1885 was one of the first to attempt an adequate description of the genus Proteus. Subsequent authors (Moltke, 1927; Wenner and Rettger, 1919; Rustigian and Stuart, 1941; Cook, 1948; Perch, 1948) have extended his study and have refined the definition. An admirable historical review is given by Krikler (1953).
For the purpose of identifying organisms as Proteus in the present study, Kauffmann's (1954) definition was adopted:

"Motile rods conforming to the definition of Enterobacteriaceae, i.e., ... a large family of Gram-negative, non-sporing rods, either motile with peritrichous flagella or non-motile. They grow on ordinary media and ferment glucose rapidly with or without gas production. They reduce nitrates to nitrites."

In addition, Proteus has the following biochemical characters:

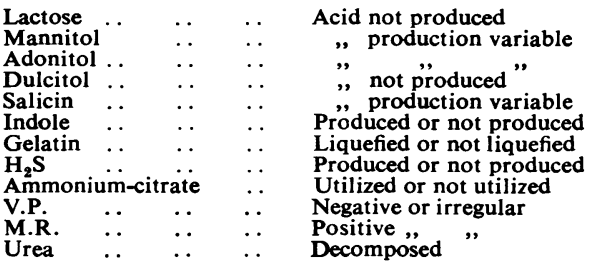

In the present investigation, the following were used as a screening test:

\begin{tabular}{|c|c|c|c|c|}
\hline $\begin{array}{l}\text { Glucose } \\
\text { Dulcite }\end{array}$ & $\cdots$ & $\because$ & $\cdots$ & $\begin{array}{l}\text { Acid with or without gas } \\
\text {," not produced }\end{array}$ \\
\hline Lactose & . & $\cdots$ & $\ldots$ & ", , , , \\
\hline Urea & $\ldots$ & $\cdots$ & . & $\begin{array}{l}\text { Rapidly decomposed } \\
\text { form ammonia }\end{array}$ \\
\hline
\end{tabular}

Organisms not conforming were rejected, and therefore the study does not embrace the Providence group.

For testing urease production, Christensen's medium as modified by Maslen (1952) was used. Rapid urease production (three to four hours and sometimes up to but not exceeding six hours at $37^{\circ} \mathrm{C}$.) was the criterion.

Kauffmann's classification of species within the genus Proteus according to biochemical characteristics is simple and agrees well with general usage and with the findings of other workers such as Rustigian and Stuart (1941) and Cook (1948). It was therefore adopted in this study as a base-line. The criteria applied were fermentation of mannitol, maltose, and xylose; the production of $\mathrm{H}_{2} \mathrm{~S}$ and indole; and the liquefaction of gelatin.

According to Kauffmann, typical reactions of Proteus species with these substrates are as follows. 


\begin{tabular}{|c|c|c|c|c|}
\hline & P. vulgaris & P. mirabilis & P. morganii & P. rettgeri \\
\hline $\begin{array}{l}\text { Mannitol } \\
\text { Maltose } \\
\text { Xylose } \\
\mathbf{H}_{2} \mathbf{S} \\
\text { Indole } \\
\text { Gelatin }\end{array}$ & $\begin{array}{l}- \\
+ \\
\pm \\
+ \\
+\end{array}$ & $\begin{array}{l}- \\
\pm \\
+ \\
+ \\
+\end{array}$ & $\begin{array}{l}- \\
- \\
\overline{-} \\
\dot{+}) \\
\dot{-}\end{array}$ & $\begin{array}{l} \pm \\
\pm \\
- \\
\pm \\
\pm\end{array}$ \\
\hline
\end{tabular}

$(+)=$ Weak positive

With the exception of the test for gelatin liquefaction, which was done at laboratory temperature, all routine biochemical reactions were carried out at $37^{\circ} \mathrm{C}$.

\section{Methods of Proving Identity of Given Strains}

In order to trace sources of infection, some method of differentiation between species is necessary. Several methods and combinations of methods are theoretically possible.

The method used in this study was a combination of biochemical species typing and Dienes' phenomenon (Dienes, 1946). Initially all strains isolated were swarmed against each other. Where the biochemical type was the same and pairs swarmed into each other without any line of demarcation, they were accepted as the same strain. It was, however, found that differentiation by Dienes' phenomenon was not giving reliable results in our hands, since different biochemical strains occasionally swarmed together, though not apparently in phase C (Story, 1954; Belyavin, 1951). The use of Dienes' phenomenon was therefore abandoned in the later part of the study.

\section{Search for Sources of Infection}

Krikler (1953) and Story (1954) found that when a strain of Proteus was isolated from an infection, the same strain could frequently be isolated from the patient's rectum. They concluded that these Proteus infections were autogenous. Both authors, however, took rectal swabs after the infection had arisen, and admitted that this method of sampling might be suspect.

In the present study rectal swabs were taken from all patients on admission to the urological ward over a period of several months. These swabs were plated on blood agar without " dispersol " L.N. and also incubated overnight in "selenite" F broth as an enrichment medium. Subcultures were subsequently made on blood agar.

Proteus was isolated from four of the 66 swabs examined. Seven of these 66 patients subsequently developed urinary Proteus infections. None of these seven patients had yielded Proteus from their rectal swabs. None of the four patients whose rectal swabs were positive developed urinary Proteus infections.

Consequently a second series of rectal swabs was taken from patients with known Proteus infections of the urinary tract. Twenty patients were examined and nine yielded Proteus. The urinary and rectal swab strains from these nine patients were compared biochemically and by Dienes' phenomenon with the following results: Identical biochemically and by Dienes' phenomenon Different biochemically and doubtful by Dienes' phenomenon .. Identical biochemically and different by Dienes' phenomenon . . Different by both criteria

A third series of patients was then studied. Rectal swabs were taken on admission from 56 patients. Where a Proteus was isolated it was kept. Rectal swabs were then taken from those patients in the series who subsequently developed Proteus urinary or wound infections, and the similarity of strains on biochemical testing compared, with the following results:

(a) PATIENTS DEVELOPING A SUBSEQUENT PROTEUS INFECTION

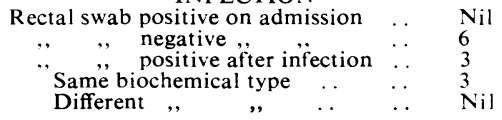

TABLE I

RESULTS OF BIOCHEMICAL TYPING OF 147 STRAINS OF PROTEUS

\begin{tabular}{|c|c|c|c|c|c|c|c|c|c|}
\hline \multirow{2}{*}{ Source } & \multicolumn{8}{|c|}{ Strain } & \multirow{2}{*}{ Total } \\
\hline & P. vulgaris & P. mirabilis & P. morganii & $P$. rettgeri & Atypical 1 & Atypical 2 & Atypical 3 & Atypical 4 & \\
\hline $\begin{array}{l}\text { Male urogenital ward: } \\
\text { Urine } \\
\text { Wound swabs } \\
\text { Rectal }\end{array}$ & $\begin{array}{l}3 \\
2 \\
3 \\
\end{array}$ & $\begin{array}{r}7 \\
1 \\
10\end{array}$ & $\begin{array}{c}1 \\
\text { Nil } \\
.\end{array}$ & $\begin{array}{c}4 \\
1 \\
\text { Nil }\end{array}$ & $\begin{array}{r}37 \\
4 \\
1\end{array}$ & $\begin{array}{c}3 \\
1 \\
\mathrm{Nil}\end{array}$ & $\begin{array}{c}\mathrm{Nil} \\
,, \\
,,\end{array}$ & $\begin{array}{c}4 \\
1 \\
\text { Nil }\end{array}$ & $\begin{array}{l}59 \\
10 \\
14\end{array}$ \\
\hline Total (urogenital ward) & 8 & 18 & 1 & 5 & 42 & 4 & , & 5 & 83 \\
\hline 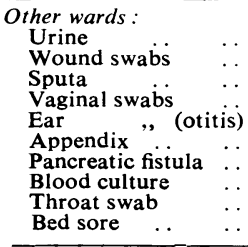 & $\begin{array}{c}\text { Nil } \\
1 \\
3 \\
1 \\
\text { Nil } \\
, " \\
, " \\
, " \\
\ddot{, "}\end{array}$ & $\begin{array}{c}7 \\
6 \\
14 \\
3 \\
3 \\
1 \\
1 \\
\text { Nil } \\
1 \\
1\end{array}$ & $\begin{array}{c}\text { Nil } \\
\dddot{1} \\
\text { Nil } \\
,, \\
,, \\
, " \\
,,\end{array}$ & $\begin{array}{c}1 \\
\text { Nil } \\
, " \\
, " \\
\text { ", } \\
, " \\
, "\end{array}$ & $\begin{array}{c}2 \\
2 \\
1 \\
\text { Nil } \\
,, \\
, " \\
,, \\
,, \\
,,\end{array}$ & $\begin{array}{c}2 \\
3 \\
4 \\
1 \\
1 \\
1 \\
\dddot{1} \\
\text { Nil } \\
\text {,, }\end{array}$ & $\begin{array}{c}\dddot{1} \\
\text { Nil } \\
,, \\
, \\
, " \\
, " \\
, "\end{array}$ & $\begin{array}{c}1 \\
\text { Nil } \\
, \\
, \\
, \\
,, \\
, " \\
, "\end{array}$ & $\begin{array}{r}13 \\
13 \\
23 \\
5 \\
4 \\
2 \\
1 \\
1 \\
1 \\
1\end{array}$ \\
\hline Total (other wards) . & 5 & 37 & 1 & 1 & 5 & 13 & 1 & 1 & 64 \\
\hline Overall total & 13 & 55 & 2 & 6 & 47 & 17 & 1 & 6 & 147 \\
\hline
\end{tabular}


(b) PATIENTS NOT DEVELOPING A SUBSEQUENT PROTEUS INFECTION

$\begin{array}{ccc}\text { Rectal swab positive on admission } \quad \ldots & 10 \\ \text { "Total swabs examined on admission } & 40 \\ \text { To } & 56\end{array}$

In spite of the surprisingly low incidence of Proteus in rectal swabs from the 122 patients in the first and third series ( $9 \%$ as compared with Rustigian and Stuart's figures of $26.3 \%$ ) (Rustigian and Stuart, 1945) these results are believed to suggest that in our series urinary infection did not arise from the patient's own faeces, but rather that the perineum was infected secondarily after the urinary infection had arisen.

Successful control of post-operative urinary infections due to Ps. pyocyanea has been reported recently (Pyrah, Goldie, Parsons, and Raper, 1955). It appeared that case-to-case infection was responsible, and one reservoir incriminated was the drainage bottle. A special cap for the bottle was devised by these authors to limit spread.

Samples of urine from seven Winchester bottles into which indwelling catheters were draining were therefore examined. From all seven of these bottles Proteus was grown. Proteus was also isolated from three out of five blood agar plates exposed during bed-making under the beds of patients with known urinary Proteus infections.

The spread of Proteus infections probably follows a pattern similar to that demonstrated by Pyrah et al. for Ps. pyocyanea.

\section{Results}

The results of biochemical typing of 147 strains of Proteus from various sources are shown in Table I. Details of reactions of atypical strains are shown in Table II and their distribution in Table III.

TABLE II

BIOCHEMICAL REACTIONS OF ATYPICAL STRAINS

\begin{tabular}{|c|c|c|c|c|c|c|}
\hline & & & $\underset{1}{\text { Atypical }}$ & $\underset{2^{*}}{\text { Atypical }}$ & Atypical & $\underset{4 \dagger}{\text { Atypical }}$ \\
\hline $\begin{array}{l}\text { Glucose } \\
\text { Dulcite } \\
\text { Lactose } \\
\text { Urease } \\
\text { Nitrate } \\
\end{array}$ & $\begin{array}{l}\cdots \\
\cdots \\
\cdots \\
\cdots \\
\end{array}$ & $\begin{array}{l}. . \\
\cdots \\
\cdots \\
\cdots \\
.\end{array}$ & $\begin{array}{l}\text { Ag. } \\
\text { Neg. } \\
\Rightarrow " \\
+ \\
\text { Reduced }\end{array}$ & $\begin{array}{l}\text { Ag. } \\
\text { Neg. } \\
\Rightarrow+ \\
\text { Reduced } \\
\end{array}$ & $\begin{array}{l}\text { Ag. } \\
\text { Neg. } \\
"=+ \\
\text { Reduced }\end{array}$ & $\begin{array}{l}\text { (A) } \\
\text { Neg. } \\
\Rightarrow+ \\
\text { Reduced }\end{array}$ \\
\hline $\begin{array}{l}\text { Mannitol } \\
\text { Maltose } \\
\text { Xylose } \\
\mathbf{H}_{2} \mathbf{S} \\
\text { Gelatin } \\
\text { Indole } \\
\text { Citrate }\end{array}$ & $\begin{array}{l}. . \\
\cdots \\
\cdots \\
\cdots \\
\cdots\end{array}$ & $\begin{array}{l}. . \\
\cdots \\
\cdots \\
\cdots \\
\cdots \\
.\end{array}$ & $\begin{array}{l}\text { Neg. } \\
\text { Ag. } \\
, " \\
+ \\
+ \\
\text { Neg. } \\
,,\end{array}$ & $\begin{array}{l}\text { Neg. } \\
\text { Ag. } \\
+ \\
+ \\
+ \\
\text { Neg. }\end{array}$ & $\begin{array}{l}\text { Neg. } \\
\text { Ag. } \\
+ \\
\text { Neg. } \\
\text { Neg. }\end{array}$ & $\begin{array}{l}\text { (A) } \\
\text { Neg. } \\
(A) \\
\text { Neg. } \\
+ \\
+\end{array}$ \\
\hline
\end{tabular}

* Two strains recorded as atypical 2 were anaerogenic. + Strains recorded as atypical 4 were non-spreaders.

During part of the investigation all strains of Proteus isolated in the laboratory except those isolated from faeces were typed.

Atypical 1.-This spreading organism appears to be an indole-negative variant of $\boldsymbol{P}$. vulgaris.
TABLE III

DISTRIBUTION OF ATYPICAL STRAINS

\begin{tabular}{|c|c|c|c|c|}
\hline & & & Atypical & Typical \\
\hline $\begin{array}{l}\text { Male urogenital ward } \\
\text { Urine } \\
\text { Wound swabs } \\
\text { Rectal ," }\end{array}$ & $\begin{array}{l}\text { : } \\
\cdots \\
\cdots\end{array}$ & $\begin{array}{l}\ldots \\
\ldots \\
\ldots\end{array}$ & $\begin{array}{r}44 \\
6 \\
1\end{array}$ & $\begin{array}{r}15 \\
4 \\
13\end{array}$ \\
\hline Total & $\ldots$ & $\ldots$ & 51 & 32 \\
\hline $\begin{array}{l}\text { Other wards: } \\
\text { Urine } \\
\text { Wound swabs } \\
\text { Sputa } \\
\text { Vaginal swabs } \\
\text { Ear } \\
\text { Appendix ". } \\
\text { Pancreatic fistula } \\
\text { Blood culture } \\
\text { Throat swab } \\
\text { Bed sore . . }\end{array}$ & $\begin{array}{l}\ldots \\
\ldots \\
\ldots \\
\cdots \\
\ldots \\
\cdots \\
\cdots \\
\cdots\end{array}$ & $\begin{array}{l}\ldots \\
\ldots \\
\ldots \\
\ldots \\
\ldots \\
\ldots \\
\ldots \\
\ldots\end{array}$ & $\begin{array}{l}5 \\
6 \\
5 \\
1 \\
1 \\
1 \\
-1 \\
-\end{array}$ & $\begin{array}{r}8 \\
7 \\
18 \\
4 \\
3 \\
1 \\
1 \\
1 \\
1\end{array}$ \\
\hline Total & $\ldots$ & $\ldots$ & 20 & 44 \\
\hline
\end{tabular}

Reed (1942) has described strains of gas gangrene anaerobes which are atypical in giving a negative indole reaction. He showed that culcures of these organisms destroy indole. All 47 of our atypical 1 strains were tested for ability to destroy indole in peptone water cultures. Results were uniformly negative.

Rustigian and Stuart (1941) examined 69 strains of $P$. vulgaris, and found four which were indole negative. Of our 60 strains of $P$. vulgaris, 47 were indole negative. Neither the addition of potassium persulphate nor the use of amyl alcohol as extractive in place of ether changed the reaction to positive in any of these strains, which were tested by three independent observers and incubated for at least 14 days before being recorded as negative.

Atypical 2: a Spreader.-This has provisionally been classifled as an indole-positive variant of $P$. mirabilis. Seventeen of our 72 strains of $P$. mirabilis were indole positive.

Atypical 3: a Non-spreader.-This has been classified provisionally as xylose-positive $P$. morganii. One of our three strains of $P$. morganii was atypical in this respect.

Atypical 4: a Non-spreader.-We have classified this provisionally as a xylose-positive variant of $P$. rettgeri, in spite of the doubiful $\mathrm{H}_{2} \mathrm{~S}$ reaction. Six of our 12 strains of $P$. rettgeri were xylose positive, producing acid only in 24 hours.

\section{Discussion and Conclusions}

The high incidence of atypical 1 strains in urines on the urological ward ( 37 out of 59 strains of Proteus isolated) as compared with other wards (two out of 13) suggests a local reservoir or other conditions favouring this strain, whilst their virtual 
absence from rectal swabs positive for Proteus taken on the urological ward (one out of 14) supports our contention that urological patients do not infect themselves from their own rectums.

The extended use of Dienes' phenomenon has given equivocal results in some cases. These may or may not have been due to organisms tested being in Phase C (Belyavin, 1951), which may give rise to false negatives due to different serological strains swarming together. Our main conclusions, therefore, are based on biochemical findings and on the distribution of biochemical types.

We appear to have obtained a clear-cut pattern of the distribution of Proteus throughout the hospital by using simple biochemical tests which divide the organisms into eight types, four typical and four atypical.

Based on the distribution of these biochemical types in urines and in rectal swabs, we conclude that Proteus spreads from case to case in the male urological ward we have studied. We also believe that this factor is more important in the spread of Proteus than is auto-infection from the patient's own rectal flora.

These conclusions are further borne out by the results of examining rectal swabs before and after urinary Proteus infections had arisen. Thirteen of 122 swabs taken before infection yielded Proteus. None of the patients from whom these 13 swabs were taken developed urinary Proteus infections. Thirteen patients whose swabs did not yield Proteus subsequently developed urinary infections. Of 26 patients with established Proteus infections, 12 yielded Proteus from rectal swabs. Of these 12 organisms, four strains were identical biochemically. (We have frequently observed mixed urinary infections including Proteus, Bact. coli, and/or Strep. faecalis, and it must be confessed that we have not succeeded in fitting this observation satisfactorily into our conclusions.)

We consider that one of the main reservoirs of infection is the Winchester bottle into which patient's bladders are drained. We have experimented with several antiseptics and have found that, provided the Winchester bottles are sterilized after changing (bedpan sterilizers are used for this purpose), the addition to the bottles of $2 \mathrm{oz}$. of a
$1.0 \%$ solution of the quaternary ammonium compound, B-phenoxy-ethyl-dimethyl-dodecyl ammonium bromide, keeps them sterile until they are full and due to be changed.

\section{Summary}

An account is given of methods used in a study of the spread of Proteus infections in a male urological ward.

Results of tests carried out on 147 strains of Proteus isolated during this study are reported, and four apparently stable variants of the usually recognized species are described.

Reasons are given for the opinion that case-tocase infection, with a persistent local reservoir, is mainly responsible for urinary infections in the ward we have studied.

Our thanks are due to Mr. H. K. Vernon and Mr. J. Burke, consultant surgeons, St. James' Hospital, Balham, for helpful criticism and access to clinical material; to Mrs. N. Ojehomon, who carried out most of the bench work; and to Mr. D. Goode, senior scientific officer, R.A.M. College, Millbank, who confirmed biochemical findings on some of our strains, and was of great assistance in freeze-drying representative cultures.

The work here reported is part of a study carried out under a research grant from the South-west Metropolitan Regional Hospital Board.

\section{REFERENCES}

Belyavin, G. (1951). J. gen. Microbiol., 5, 197.

Cook, G. T. (1948). J. Path. Bact., 60, 171.

Dienes, L. (1946). Proc. Soc. exp. Biol. (N.Y.), 63, 265.

Hauser, G. (1885). Über Fäulnissbacterien und deren Beziehungen zur Sepicämie. Vogel, Leipzig.

Kauffmann, F. (1954). Enterobacteriaceae, 2nd ed. Munksgaard, Copenhagen.

Krikler, M. S. (1953), The Serology of Proteus Vulgaris. Thesis for the degree of Doctor of Philosophy, University of London.

Mackie, T. J., and McCartney, J. E. (1948). Handbook of Practical Bacteriology, p. 333. Livingstone, Edinburgh.

Maslen, L. G. C. (1952). Brit. med. J., 2, 545.

Moltke, O. (1927). Contributions to the Characterization and Systematic Classification of Bac. proteus vulgaris Hauser. Munksgaard, Copenhagen.

Perch, B. (1948). Acta path. microbiol. scand., 25, 703.

Pyrah, L. N., Goldie, W., Parsons, F. M., and Raper, F. P. (1955). Lancet, 2, 314.

Reed, R. W. (1942). J. Bact., 44, 425.

Rustigian, R., and Stuart, C. A. (1941). Proc. Soc. exp. Biol. (N.Y.), 47, 108.

-1 (1945). J. Bact., 49, 419.

Story, P. (1954). J. Path. Bact., 68, 55.

Wenner, J. W., and Rettger, L. F. (1919). J. Bact., 4, 331. 